\title{
Acaricidal activity of essential oils for the control of honeybee (Apis mellifera) mites Tropilaelaps mercedesae under laboratory and colony conditions
}

\author{
Veeranan ChAIMANEE $^{1}\left(\mathbb{D}\right.$, Natapot WARRIT $^{2}$, Thummanoon BoonmeE ${ }^{1}$, \\ Jeffery S. PetTis ${ }^{3,4}$ \\ ${ }^{1}$ Department of Agro-Industrial Biotechnology, Maejo University Phrae Campus, Rong Kwang, Phrae 54140, Thailand \\ ${ }^{2}$ Department of Biology and Center of Excellence in Entomology, Faculty of Science, Chulalongkorn University, \\ Bangkok 10330, Thailand \\ ${ }^{3}$ Pettis and Assoc. LLC, Salisbury, MD 21801, USA \\ ${ }^{4}$ USDA-ARS Bee Research Laboratory, Beltsville, MD 20705, USA
}

Received 5 June 2020 - Revised 18 December 2020 - Accepted 3 February 2021

\begin{abstract}
Tropilaelaps spp. mites are considered a major parasite of honeybees. In this study, essential oils (EOs) of 11 plant species were evaluated for acaricidal activity under laboratory and field conditions. Five adult mites per petri dish and ten adult worker bees per plastic cup cage were exposed to different concentrations of each essential oil $(0.1,0.5,1.0,5.0$, and $10.0 \%(\mathrm{v} / \mathrm{v}))$. The essential oil of Piper betle (betel) showed the highest acaricidal activity in laboratory testing. Additionally, most EOs showed low toxicity to adult honeybees in a lab assay. Piper betle, Amomum krervanh, and Zanthoxylum limonella were then tested in whole colonies using cardboard strips soaked in $10 \mathrm{~mL}$ of each essential oil at various concentrations, every week for 4 weeks. Amomum krervanh at $10 \%$ (v/v) and $P$. betel at $5.0 \%(\mathrm{v} / \mathrm{v})$ decreased mite populations after 30 days. We further tested grease and a sponge as application methods to deliver A. krervanh, with no significant impact on mites. Although several essential oils demonstrated acaricidal activity against Tropilaelaps under laboratory conditions, the EOs tested did not significantly reduce mites under colony conditions. Therefore, the concentration and colony delivery methods of these promising EOs warrant further investigation.
\end{abstract}

\section{Tropilaelaps / acaricidal activity / $\mathrm{LC}_{50}$ / Apis mellifera / Piper betle / Amomum krervanh}

\section{INTRODUCTION}

Tropilaelaps spp. are ectoparasitic mites of Apis honeybees in Asia. The original host of Tropilaelaps mites is recognized as the giant honeybee, Apis dorsata, but recently they have become a serious pest of managed honeybees, Apis mellifera, in many Asian countries (Anderson and Morgan 2007). A tropical or sub-tropical climate is considered to be a major factor in the prevalence

Corresponding author: V. Chaimanee, chveeranan@gmail.com

Handling Editor: Peter Rosenkranz of Tropilaelaps (Sammataro et al. 2000). In Thailand, Tropilaelaps are considered to be a more problematic parasite of honeybees than another honeybee mite, Varroa (Burgett et al. 1983; Buawangpong et al. 2015). Tropilaelaps reproduce rapidly and have a shorter phoretic stage than Varroa ; thus, they may outcompete Varroa mites when both mites are present (Burgett et al. 1983; Ritter and Schnieder-Ritter 1988; Buawangpong et al. 2015). Mite parasitism can cause brood mortality and colony decline (Anderson and Morgan 2007; Ritter 2008). Although there are no specific products to control Tropilaelaps mites, the synthetic chemical acaricides used to 
control Varroa mites such as Apistan $®$ (fluvalinate), Checkmite+ ${ }^{\circledR}$ (coumaphos), and Bayvarol® (flumethrin) are also effective on Tropilaelaps (Burgett and Kitprasert 1990; Camphor et al. 2005; Kongpitak et al. 2008). Additionally, several commercial products known to control Varroa were also tested for efficacy against Tropilaelaps. The results showed that the formic acid product, MiteAway Quick Strips ${ }^{\circledR}$, was the only product tested that significantly reduced mite population after 8 weeks of treatment without side effect. However, these acaricides used to control Varroa are not always effective against Tropilaelaps mites (Pettis et al. 2017). Apivar® (amitraz) was also tested to control Tropilaelaps but had little to no effect on mite populations in bee colonies (Pettis et al. 2017). Moreover, the application of some acaricides in bee colonies can affect queen performance and sperm viability in drones and impact colony growth (Atwal and Goyal 1971; Haarmann et al. 2002; Burley et al. 2008; Pettis et al. 2017). Also, the presence of chemical residues in the hive and honeybee products can be a negative effect of acaricidal use (Mullin et al. 2010; Chaimanee et al. 2019). Hence, the development of alternative mite control methods is needed. Many natural compounds and organic acids have shown promise in controlling pests and diseases in honeybees. Formic acid and thymol have both been shown to have efficacy against Tropilaelaps (Raffique et al. 2012; Pettis et al. 2017). Also, several essential oils have demonstrated acaricidal efficacy in controlling Varroa mites, such as Syzygium aromaticum, Acantholippia seriphioides, Schinus mole, Citrus aurantium, Cymbopagon flexuosus, Thymus vulgaris, and Salvia officinalis (Ruffinengo et al. 2005; Abd ElWahab and Ebada 2006; Damiani et al. 2009; Gashout and Guzmán-Novoa 2009; Bendifallah et al. 2018). As alternative control methods, essential oils have shown high acaricidal activity and low toxicity to bees. Low residues and less accumulation in honeybee products are also reported as advantages of natural compounds (Rosenkranz et al. 2010). However, the degree of mite control by essential oils in beehives is not always consistent. Efficacy is often affected by environmental conditions such as temperature and relative humidity (Bacandritsos et al. 2007).

In Thailand, there are many plant species that contain active compounds with high biological activity, including acaricidal and insecticidal activity. Plants in the family Piperaceae are members of traditional pharmacopeia in Asia and many other countries. These plants have been used to control mites, ticks, and other arthropod pests (Park et al. 2002; Silva et al. 2009; Ferraz et al. 2010). Cinnamomum spp. have shown some acaricidal activity against Varroa mites (Imdorf et al. 1999; Conti et al. 2020). Additionally, crude extracts of Amomum krervanh showed antibacterial activity against Paenibacillus larvae (Chaimanee et al. 2017).

Therefore, in this study, the bioactivity of several plant essential oils on Tropilaelaps was screened and evaluated under laboratory conditions based on their previously reported acaricidal and biological activities. The most promising essential oils were also tested for adult bee toxicity. Finally, the most promising essential oils were tested at the whole colony level to control Tropilaelaps mites using several different delivery methods under field conditions in Thailand. Our goal was to develop more environmentally sensitive control options for honeybee mites.

\section{MATERIALS AND METHODS}

\subsection{Plant species and essential oil extraction}

Eight plant species were collected fresh from Phrae province in northern Thailand and three species were purchased from an herbal store in Chiang Mai, Thailand. Different plant parts of each species were used for essential oil extraction (Table I). Plant materials were washed and dried at room temperature. Two hundred grams of each plant species was added to $1.5 \mathrm{~L}$ of distilled water, then the essential oil was extracted using a hydrodistillation method for $3 \mathrm{~h}$ or until no more essential oil was obtained. The essential oil was collected and anhydrous sodium sulfate added to remove excess water (Damiani et al. 2009). The extraction was run several times for each plant until the desired quantity of oil was obtain for the experiments. The extracts were stored at $4^{\circ} \mathrm{C}$ until used. 
Table I. Plant species were used in this study

\begin{tabular}{llll}
\hline Plant species & Common name & Part used & Origin \\
\hline Cinnamomum camphora & Camphor laurel & Leaf & Phrae province \\
Citrus hystrix & Kaffir lime & Leaf & \\
Cymbopogon citratus & Lemon grass & Stem & \\
Eucalyptus globulus & Eucalyptus & Leaf & \\
Ocimum basilicum & Basil & Leaf & \\
Ocimum sanctum & Holy basil & Leaf & \\
Piper betle & Betal & Leaf & Herbal store \\
Zanthoxylum limonella & Ma-khwaen & Fruit and seed & \\
Amomum krervanh & Cardamon & Fruit & \\
Cinnamomum sp. & Cinnamon & Stem & \\
Syzygium aromaticum & Clove & Flower & \\
\hline
\end{tabular}

\subsection{Mites}

Female mites of $T$. mercedesae were collected from honeybee colonies (A. mellifera). The hives were located at Maejo University Phrae Campus, Phrae, Thailand, and had been left untreated for Tropilaelaps in the previous 4-6 months. Sealed brood combs were removed from colonies and transported to the laboratory. Brood cells were individually uncapped and inspected for T. mercedesae . The female mites were lifted from the cells and comb surface with a fine brush and placed on honeybee larvae in petri dishes to avoid starvation. Mites that appeared newly moulted (light in color), abnormal, and/or weak (slow-moving) were removed from the experiment (Damiani et al. 2009). Healthy mites by comparison are fast moving, a darker tan color and very active and agile.

\subsection{Honeybee adults}

Frames of sealed brood were removed from healthy A. mellifera colonies and held in a wire mesh-made cage and placed in an incubator at 34 $\pm 1{ }^{\circ} \mathrm{C}$ and $70 \%$ RH. Ten newly emerged bees were placed in plastic cup cages (Evans et al. 2009) and were fed with $50 \%(\mathrm{w} / \mathrm{v})$ of sugar solution and water for 3 days at room temperature before exposure to essential oils.

\subsection{Acaricidal activity of essential oils on T. mercedesae under laboratory conditions}

The complete exposure method is described by Ruffinengo et al. (2005) and was modified to evaluate the bioactivity of the essential oils on Tropilaelaps mites. Each essential oil was dissolved in acetone to obtain concentrations of $0.1,0.5,1.0,5.0$, and $10.0 \%(\mathrm{v} / \mathrm{v})$. Our experience with other essential oil research (Nuanjohn and Chaimanee 2019) indicated that this range of dosages would cover the most likely range for acaricidal activity. Then, $100 \mu$ of each concentration was placed onto filter paper that filled the bottom of a standard $60 \times$ $15 \mathrm{~mm}$ petri dish. After $5 \mathrm{~min}$ of evaporation, five mites and two larvae were placed in each petri dish. Three replicates were run for each treatment for a total of 15 mites tested against each treatment and dose. Acetone and fluvalinate at concentration of 0.1 , $0.5,1.0,5.0$, and $10 \%(\mathrm{w} / \mathrm{v})$ were included as negative and positive control, respectively. The experiment was carried out at room temperature and all treated mites were incubated at $28 \pm 1{ }^{\circ} \mathrm{C}$ and $70 \% \mathrm{RH}$. Mortality of mites was checked at 4,24 , and $48 \mathrm{~h}$ following initial exposure. 


\subsection{Toxicity of essential oils on $A$. mellifera adults}

The vapor toxicity of essential oils to adult bees was tested using a method modified from Evans et al. (2009). Three-day-old emerged worker bees were used in this study. Concentrations of each essential oil were made at $0.1,0.5,1.0$, and $10.0 \%$ $(\mathrm{v} / \mathrm{v})$ by dilution in acetone and a $200 \mu \mathrm{l}$ aliquot of each was applied to filter paper placed on the bottom of plastic cup cages (Evans et al. 2009). Ten adult bees were placed into each cage after 5 min of solvent evaporation and held at $30 \pm 1$ ${ }^{\circ} \mathrm{C}$. Three replicate cages were run for each treatment for $n=30$ bees total. A $50 \%(w / v)$ sugar solution and water was provided on the top of the cage throughout the experiment. Acetone was run as a negative control group. Dimethoate at concentration of $0.01,0.05,0.1,0.5$, and $1.0 \%$ $(\mathrm{w} / \mathrm{v})$ was used as a positive control. Mortality was checked at $4,24,48$, and $72 \mathrm{~h}$ following initial exposure.

\subsection{Field experiment}

\subsubsection{Essential oils for control of T. mercedesae under field condition}

The field experiment was conducted in the winter during December 2016 to February 2017 (15-20 ${ }^{\circ} \mathrm{C}$ of an average temperature and $60-70 \%$ of a relative humidity) at Maejo University Phrae Campus, Phrae, Thailand. Langstroth hives with 2-3 frames of sealed brood, 1-2 frames of unsealed brood, and 1 frame of pollen were used in this study. Each hive consisted of a single Langstroth deep box with 10 frames. All hives had a laying queen and the most uniform hives were selected for inclusion in the study. Honeybee colonies that had been left untreated for mite control for the previous 4-6 months were used in the study. Colonies were assessed for adult bee and mite populations. Adult bee population density consisted of a visual inspection of each comb and adult bee coverage estimated to the nearest 0.5 frame coverage $(1=$ fully covered in adult bees). For the determination of mite infestation rate, 100 cells were opened, groups of 10 cells in a line were opened, and the observer moved at random across the sealed brood area, most often opening 50 cells on two sides of a single brood frame (Pettis et al. 2017). Colonies were then assigned into eight treatment groups with eight colonies per treatment using a stratified random design in which colonies were ranked from high to low mite infestation and treatments assigned down the rank in groups of nine colonies to ensure balanced mite levels across all treatment groups. Three essential oils A. krervanh, P. betle, and Z. limonella were chosen for the field study. Each essential oil was dissolved in liquid paraffin to obtain concentrations of 1.0 and $10.0 \%(\mathrm{v} / \mathrm{v})$ for A. krervanh and Z. limonella and 0.5 and $5.0 \%$ $(\mathrm{v} / \mathrm{v})$ for $P$. betle. Previous research with essential oils had indicated that the 1.0 and $10 \%$ dosages should cover a realistic high and low dose. Dosage regimes were designed to compare the acaricidal activity of low and high doses of each essential oil for Tropilaelaps control in beehives. Each cardboard strip $(5.0 \times 22.0 \mathrm{~cm})$ was soaked in $10 \mathrm{~mL}$ of each treatment solution. Negative controls consisted of liquid paraffin strips. Fluvalinate strips (Weipeng's manpu; Shanxi Weipeng Pharmaceutical Co., Ltd.) containing $40 \mathrm{mg}$ per strip were used as a positive control (Apistan $®$ strips were not available in Thailand). Two strips of each treatment were applied every week for 4 weeks except the fluvalinate strips, where two strips were applied twice on days 0 and 14. Although the manufacturer recommends one strip of fluvalinate for ten frames of bees and small hives requires only $1 / 2$ strip, these dosages are recommended for controlling the Varroa mites. According to Thai beekeepers, the higher doses are needed to control Tropilaelaps. Thus, two strips of fluvalinate were applied every 2 weeks to obtain the effective control in this study.

\subsubsection{Different application methods of essential oil for the control of T. mercedesae under field conditions}

In this experiment, the essential oil tested in the previous experiment that showed a high acaricidal activity (A. krervanh) was chosen to evaluate Tropilaelaps mite control using different application methods. The experiment was conducted from December 2017 to February 2018. Six 
treatments consisted of liquid paraffin strips (negative control), 1.0 and $10.0 \%(\mathrm{v} / \mathrm{v})$ of essential oil (A. krervanh) cardboard strips $(5.0 \times 22.0 \mathrm{~cm})$, $10 \%(\mathrm{v} / \mathrm{w})$ of essential oil in semi-solid vegetable grease (Crisco, USA), $10.0 \%(\mathrm{v} / \mathrm{v})$ of essential oil sponge strips $(5.0 \times 22.0 \mathrm{~cm})$, $($ Scotch-Brite, Spain), and commercially available fluvalinate strips (positive control). Colonies were assessed for mite levels and then treatments assigned for the experiment using a stratified random design as described above. Two strips or $10 \mathrm{~g}$ of grease of each treatment was applied every week for 4 weeks except the fluvalinate strips, where two strips were applied twice on days 0 and 14 . The $10 \mathrm{~g}$ of grease was used based on the experience of Thai beekeepers who use this matrix (grease) to apply other compounds.

In both field experiments, colonies were monitored for adult bee population density and mite infestation rate using the methods as described above at three time intervals, pre-treatment (day 0 ) and at ca. 30 and 60 days following the initiation of treatments (Pettis et al. 2017).

\subsection{Essential oil analysis}

The chemical composition of essential oil that showed high acaricide activity (A. krervanh) was analyzed by gas chromatography model $6890 \mathrm{~N}$ (Agilent Technologies, USA) coupled to mass spectrometer detector model 5793 inert (Agilent Technologies, USA). The gas chromatography was equipped with DB5MS capillary column $(30 \mathrm{~m} \times$ $0.25 \mathrm{~mm} \times 0.25 \mu \mathrm{m}$ film thickness, Agilent Technologies, USA). A $100 \mathrm{mg}$ of essential oil sample was diluted in $1 \mathrm{~mL}$ of hexane. The analysis was performed using helium as a carrier gas at a flow rate $1.0 \mathrm{~mL} / \mathrm{min}$. The program temperature conditions consisted in a temperature program from 50 until $280{ }^{\circ} \mathrm{C}$, with an increment of $5{ }^{\circ} \mathrm{C} / \mathrm{min}$ and maintained at this temperature for $5 \mathrm{~min}$. One microliter of the sample was injected at a constant temperature of $250{ }^{\circ} \mathrm{C}$ with a split ratio of $20: 1$. Mass spectrum was scanned from 20 to $350 \mathrm{~m} / \mathrm{z}$. The essential oil components were identified by comparing their mass spectra with those stored in the National Institute of Standards and Technology mass spectrometry library (Central Laboratory (Thailand) Co., Ltd.).

\subsection{Statistical analysis}

The $\mathrm{LC}_{50}$ values were analyzed by probit analysis using StatPlus:mac for macOS® Version v7 (AnalystSoft Inc.). Statistical analyses were performed using JMP® version 11.2 for Mac (SAS Institute Inc.). Normality of data was checked using the Shapiro-Wilk test. The non-parametric Kruskal-Wallis test was used to determine if there were significant differences in $\mathrm{LC}_{50}$ values, number of frames covered with adult bees, and number of mite-infested cells, followed by a Steel-Dwass posthoc multiple comparison to separate means when significance was found. Effect of essential oils on frames covered with adult bees and number of mite-infested cells were compared between treatment groups in each observation time.

\section{RESULTS}

\subsection{Acaricidal activity of essential oils to T. mercedesae and toxicity to honeybees under laboratory conditions}

The $\mathrm{LC}_{50}$ values for essential oils to T. mercedesae and adult honeybees at each time interval are shown in Table II. Piper betle showed the highest acaricidal activity against $T$. mercedesae mites. All mites were dead at $4 \mathrm{~h}$ of exposure at the lowest concentration tested in this study. All essential oils tested had high acaricidal activity with the $4 \mathrm{~h}$ of $\mathrm{LC}_{50}$ values ranged between 0.00002 $0.756(\% \mathrm{v} / \mathrm{v})$. Six out of eleven essential oils killed all the mites after $24 \mathrm{~h}$ of exposure. Additionally, the essential oils of A. krervanh, C. camphora L., P. betle, S. aromaticum, and $Z$. limonella showed low toxicity to adult bees $\left(4-\mathrm{h} \mathrm{CC}_{50}=7.753-26.257(\% \mathrm{v} / \mathrm{v})\right)$ when compared to dimethoate $(0.369 \% \mathrm{w} / \mathrm{v})$. Cinnamomum sp. was highly toxic to bees with $1.427 \%(\mathrm{v} / \mathrm{v})$ of $\mathrm{LC}_{50}$ at $4 \mathrm{~h}$. Clove oil had the highest selectivity ratio $(760,350)$ at $4 \mathrm{~h}$ followed by oil extracted from A. krervanh and Z. limonella (133.96 and 94.59, respectively). 


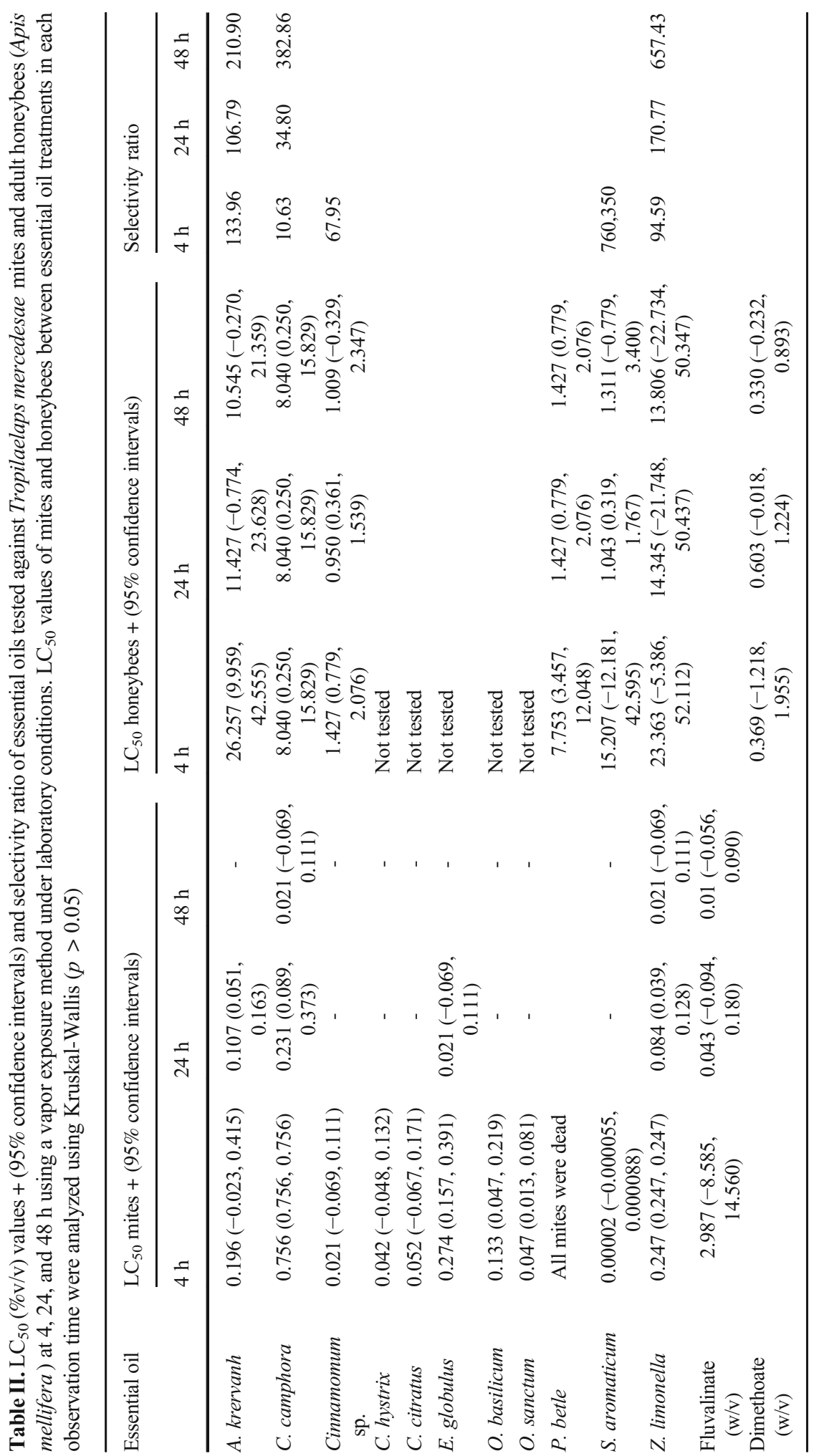




\subsection{Effect of essential oils on $T$. mercedesae control under field conditions}

We tested three essential oils, A. krervanh, $P$. betle, and $Z$. limonella, under field conditions in colonies with 4-5 frames of adult bees which is a common colony size in the tropics. The adult bees of all treatment groups, including the control group (liquid paraffin), slightly decreased over 60 days of the experiment. Bee population was on average about 2-3 frames of bees at the end of test period. All three essential oils had no significant negative effects on adult bee population (Figure 1a).

The essential oil of A. krervanh showed effects on mite populations, with mite populations reduced at 30 and 60 days of treatment when compared to the fluvalinate control group (Steel-Dwass test, $p>$ $0.05)$ (Figure 1b). Piper betle (5\% v/v) seemed to have some effect on mite levels under field conditions, but without significant differences at 30 and 60 days (Steel-Dwass test, $p>0.05$ ) (Figure 1b). However, the mite population increased at day 30 after exposure to $0.5 \%(\mathrm{v} / \mathrm{v})$ of $P$. betle. Thus, no further evaluation was conducted on these colonies at day 60 based on a lack of control evidence at day 30. The results showed that mite levels were not affected by $Z$. limonella at both concentrations $1 \%$ and $10 \%(\mathrm{v} / \mathrm{v})$ on day 30 (Figure $1 \mathrm{~b})$.

\subsection{Acaricidal activity of essential oil of A. krervanh with different applications}

To investigate the efficacy of the essential oil of A. krervanh, we tested different application methods and compared the acaricidal activity on Tropilaelaps . Essential oil $(10 \% \mathrm{v} / \mathrm{v})$ was added in cardboard, grease, and sponge and applied to colony. In this trial, bees were unaffected by $A$. krervanh at 30 and 60 days (Figure 2a). Mite populations decreased when the essential oil was applied in grease or sponge on day 60 but there were no significant differences between all treatment groups (Steel-Dwass test, $p>0.05$ ) (Figure 2b).

\subsection{Chemical composition of A. krervanh essential oils}

Sixty components have been identified in essential of A. krervanh (Table III). They are mainly composed of monoterpenes with 1,8-cineole (77.17\%), $\beta$-Pinene $(8.43 \%)$, and $\alpha$-Terpineol (4.58\%); their detailed composition is presented in Table III.

\section{DISCUSSION}

Tropilaelaps mites are another honeybee ectoparasites that has spread in Asia and they are very problematic where Apis mellifera is managed in Asia. These mites reproduce rapidly and have a shorter phoretic stage than Varroa, making them more problematic. One product, amitraz that is commonly used to control Varroa was not effective in controlling Tropilaelaps under tropical conditions (Pettis et al. 2017). Therefore, in this study, we tested the acaricidal activity of some promising essential oils in controlling T. mercedesae under laboratory and field conditions. The goal was to screen several essential oils and then begin to field test the oils that showed the highest efficacy in lab assays and low adult bee toxicity. The essential oils tested in this research killed mites at a greater rate than fluvalinate after $4 \mathrm{~h}$ of exposure under laboratory conditions, especially $P$. betle, which killed all mites in under $4 \mathrm{~h}$ of exposure. Previous research with the genus Piper has shown acaricidal activity against mites and ticks (Silva et al. 2009; Ferraz et al. 2010; Araújo et al. 2012; da Silva Lima et al. 2014; Vinturelle et al. 2017) but had not been tested on bee mites to our knowledge. The essential oil from $P$. betle leaves is dominated by phenylpropanoids and aromatic compounds (up to $40 \%$ of eugenol and up to $40 \%$ carvacrol and chavicol) (Salehi et al. 2019) which could be related to its acaricidal activity. Other typical components are terpinen-4ol, safrole, allyl pyrocatechol monoacetate, eugenyl acetate, hydroxyl chavicol, and piper betol (Pradhan et al. 2013; Dwivedi and Tripathi 2014; Salehi et al. 2019). Some essential oils tested in this study were highly effective against Tropilaelaps with low toxicity to adult bees compared to dimethoate which was used as a positive control. Some essential oils were chosen for further testing for mite control at the whole colony level. We must caution, however, that different plant parts and extraction methods could cause variation in both acaricidal and bee toxicity levels. 

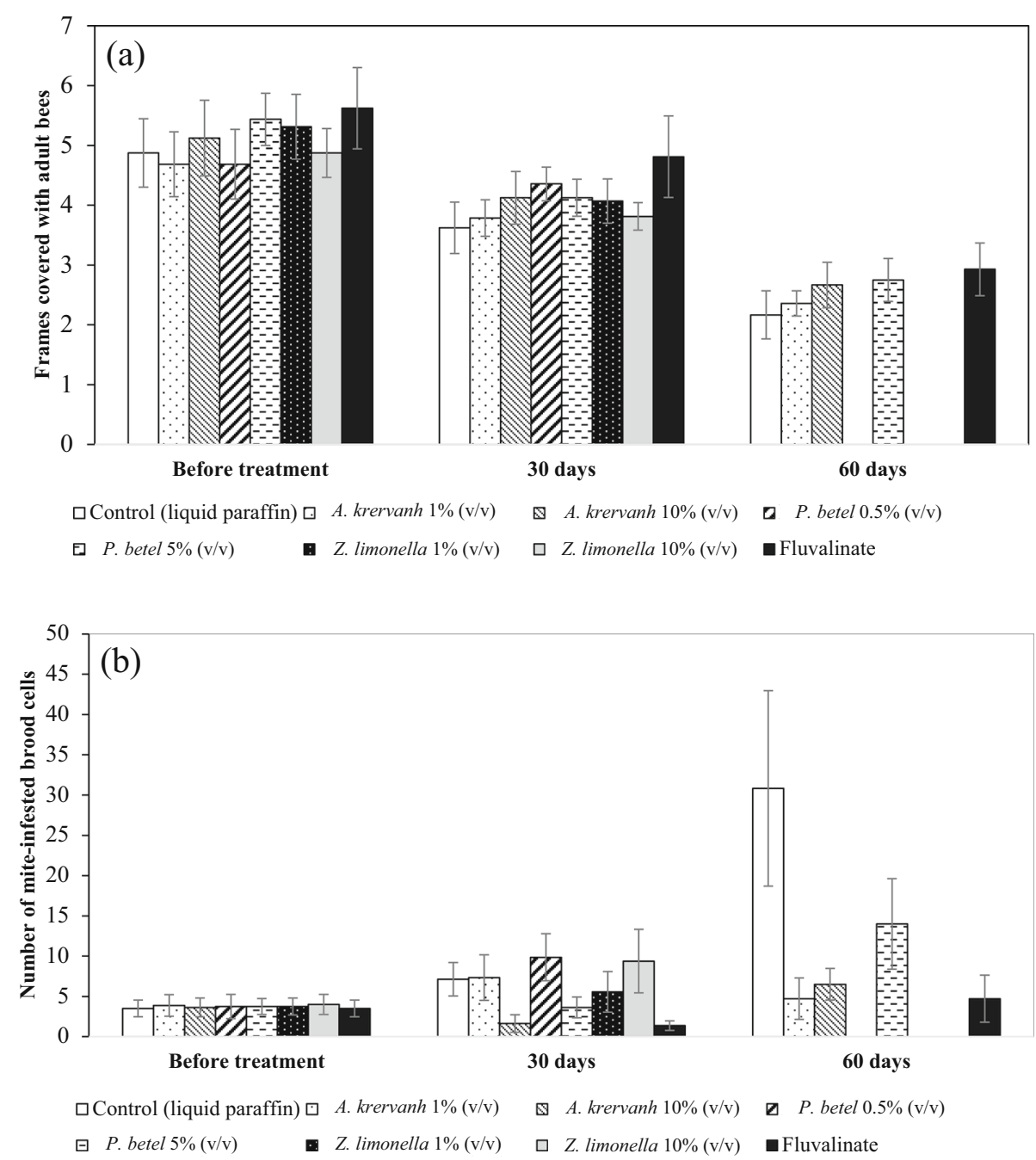

Figure 1. Average number of frames covered with adult bees $(\mathbf{a})$ and mite populations $(\mathbf{b})$ in honeybee colonies $(n$ $=8 /$ treatment group) after exposure to the essential oil of Amomum krervanh, Piper betle (L.), and Zanthoxylum limonella compared to controls (liquid paraffin) and fluvalinate at each observation period (before treatment and 30 and 60 days after treatment) (Kruskal-Wallis $\mathrm{H}$ and Steel-Dwass test, $p>0.05$ ).

Thus, more testing is needed and or the identification of the more active fractions of the most promising essential oils. EOs vary in content and concentration of the active acaricidal compounds depending on many factors such as variety of plant used, locality, and the method of extraction (Table IV). These factors can result in variable results. Five essential oils, $C$. hystrix, C. citratus, E. globulus, O. basilicum, and $O$. sanctum, were not tested for adult bee toxicity. Although, high acaricidal effects were observed, the yield of essential oils from these plants was low by this extraction method and thus further testing was limited.

We therefore performed the field experiments with A. krervanh, $P$. betle, and $Z$. limonella based on their acaricidal activity, toxicity on bees, and essential oil yield. The mite infestation rate was low in all colonies used in these studies, and this could be due to several factors such as weather and reduced honeybee brood rearing at this time of year. Even with low mite levels, we 

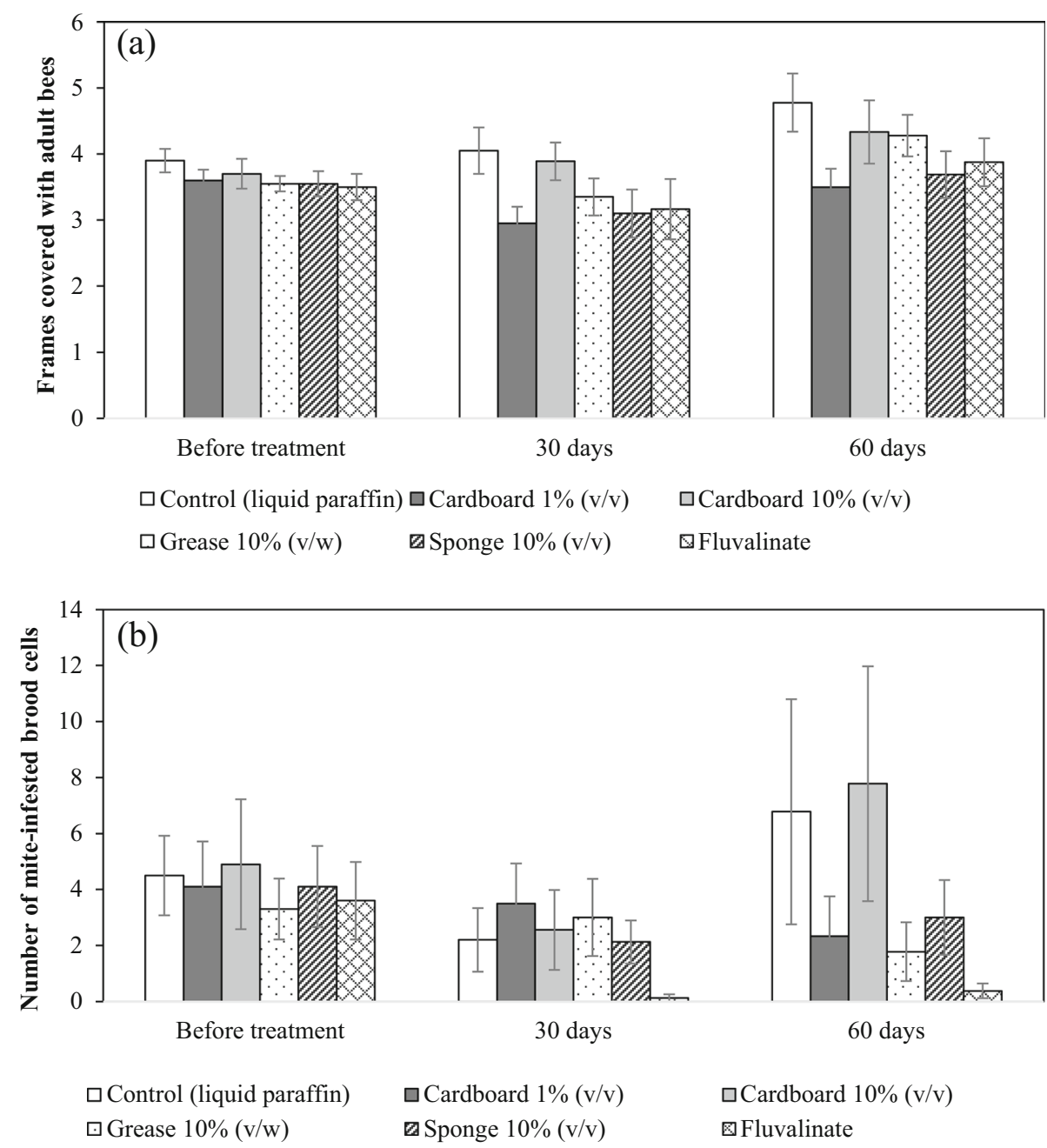

Figure 2. Average number of frames covered with adult bees (a) and mite populations (b) in honeybee colonies after exposure to the essential oil of Amomum krervanh with the different delivery methods (cardboard, grease, and sponge) at each observation period (before treatment and 30 and 60 days after treatment) (Kruskal-Wallis $\mathrm{H}$ and Steel-Dwass test, $p>0.05$ ).

demonstrated that A. krervanh was effective in reducing mite populations at the end of the experimental period (60 days after initial exposure). Higher concentration of $10 \%(\mathrm{v} / \mathrm{v})$ did not significantly reduced mite levels. It might be due to the variation between colonies such as genetic variation or that the higher concentration of A. krervanh caused significant changes in bee behaviors within the colony that limited the distribution of the higher dose (i.e., avoiding the strip). The 1,8-Cineloe was found as a major chemical composition in the essential oil of
A. krervanh (Diao et al. 2014). Many studies demonstrated the biological activities of Amomum species including antibacterial activity and insecticidal activity (Mathew et al. 2003; Pulbutr et al. 2012; Satyal et al. 2012; Singtothong et al. 2013; Diao et al. 2014; Chen et al. 2018). Additionally, the ethanolic extract of A. krervanh showed the antimicrobial activity on Paenibacillus larvae which is the causative agent of American foulbrood in honeybees (Chaimanee et al. 2017) the most serious bacterial disease of honeybees. 
Table III. Chemical composition of A. krervanh essential oil obtained by hydro-distillation method using GC-MS

No. Compound

RT.

(Min)
Total area

$(\%)$
Relative area

(\%)

\begin{tabular}{|c|c|c|c|c|}
\hline 1 & 2-Methyl-3-buten-2-ol & 8.69 & 0.017 & 0.02 \\
\hline 2 & Alpha-Phellandrene & 9.05 & 0.082 & 0.11 \\
\hline 3 & Alpha-Pinene & 9.31 & 2.036 & 2.64 \\
\hline 4 & Camphene & 9.86 & 0.053 & 0.07 \\
\hline 5 & Oxirane, 2,2-dimethyl-3-propyl-Hexane, 2,3-epoxy-2-methyl & 10.23 & 0.016 & 0.02 \\
\hline 6 & Sabinene & 10.69 & 0.466 & 0.60 \\
\hline 7 & Beta-Pinene & 10.89 & 8.430 & 10.92 \\
\hline 8 & 2-Propenamide, N-ethyl- & 11.05 & 0.083 & 0.11 \\
\hline 9 & Beta-Myrcene & 11.28 & 0.733 & 0.95 \\
\hline 10 & Beta-Phellandrene & 11.84 & 0.250 & 0.32 \\
\hline 11 & 2-Carene & 12.21 & 0.107 & 0.14 \\
\hline 12 & 1,8-Cineole/Eucalyptol & 12.85 & 77.17 & 100.00 \\
\hline 13 & Trans-beta-Ocimene & 13.22 & 0.072 & 0.09 \\
\hline 14 & Gamma-Terpinene & 13.60 & 0.414 & 0.54 \\
\hline 15 & Gamma-Terpinene & 13.99 & 0.331 & 0.43 \\
\hline 16 & 1-methyl-4-(1-methylethylidene)-Cyclohexene & 14.45 & 0.127 & 0.16 \\
\hline 17 & D-Fenchone & 14.58 & 0.376 & 0.49 \\
\hline 18 & Linalool & 14.95 & 0.618 & 0.80 \\
\hline 19 & Fenchyl alcohol & 15.55 & 0.042 & 0.05 \\
\hline 20 & Delta-3-Carene & 15.71 & 0.021 & 0.03 \\
\hline 21 & DL-Camphor & 16.42 & 0.070 & 0.09 \\
\hline 22 & Camphene & 16.67 & 0.018 & 0.02 \\
\hline 23 & Pinocarvone & 16.89 & 0.027 & 0.03 \\
\hline 24 & Delta-Terpineol & 17.15 & 0.332 & 0.43 \\
\hline 25 & 4-Terpineol & 17.46 & 0.764 & 0.99 \\
\hline 26 & Alpha-4-trimethyl-Benzenemethanol & 17.67 & 0.049 & 0.06 \\
\hline 27 & Alpha-Terpineol (p-menth-1-en-8-ol) & 17.97 & 4.587 & 5.94 \\
\hline 28 & Sabinol & 18.15 & 0.092 & 0.12 \\
\hline 29 & Cycloheptane, 1,3,5-tris(methylene)- & 19.21 & 0.026 & 0.03 \\
\hline 30 & 2-Methyl-5-isopropenyl-2-cyclohexenone & 19.31 & 0.024 & 0.03 \\
\hline 31 & Carvotanacetone & 19.46 & 0.057 & 0.07 \\
\hline 32 & Phenol, 5-methyl-2-(1-methylethyl)- & 20.61 & 0.029 & 0.04 \\
\hline 33 & Phenol, 2-methyl-5-(1-methylethyl)- & 20.84 & 0.159 & 0.21 \\
\hline 34 & p-mentha-1(7),4(8)-diene & 21.24 & 0.107 & 0.14 \\
\hline 35 & Allo-Ocimene & 22.16 & 0.865 & 1.12 \\
\hline 36 & Delta-3-Carene & 22.44 & 0.028 & 0.04 \\
\hline 37 & Alpha-Copaene & 22.95 & 0.067 & 0.09 \\
\hline 38 & Beta-Elemene & 23.31 & 0.016 & 0.02 \\
\hline 39 & Alpha-Santalene & 24.07 & 0.100 & 0.13 \\
\hline 40 & Alpha-Bergamotene & 24.42 & 0.057 & 0.07 \\
\hline 41 & Beta-Farnesene & 24.94 & 0.032 & 0.04 \\
\hline
\end{tabular}

\section{Springer}


Table III (continued)

\begin{tabular}{|c|c|c|c|c|}
\hline No. & Compound & $\begin{array}{l}\text { RT. } \\
\text { (Min) }\end{array}$ & $\begin{array}{l}\text { Total area } \\
(\%)\end{array}$ & $\begin{array}{l}\text { Relative area } \\
(\%)\end{array}$ \\
\hline 42 & Alpha-Humulene & 25.03 & 0.023 & 0.03 \\
\hline 43 & D-Germacrene & 25.67 & 0.017 & 0.02 \\
\hline 44 & Beta-Chamigrene & 25.73 & 0.025 & 0.03 \\
\hline 45 & Beta-Selinene & 25.89 & 0.159 & 0.21 \\
\hline 46 & $\begin{array}{l}\text { Naphthalene, 2,3,4,4a,5,6-hexahydro-1,4a-dimethyl-7-(1- } \\
\text { methylethyl)- }\end{array}$ & 26.08 & 0.119 & 0.15 \\
\hline 47 & Alpha-Bisabolene & 26.31 & 0.216 & 0.28 \\
\hline 48 & Gamma-Cadinene & 26.46 & 0.039 & 0.05 \\
\hline 49 & Germacrene B & 26.57 & 0.056 & 0.07 \\
\hline 50 & $\begin{array}{l}\text { (+)-endo-6-methyl-2-methylene-6-(4-methyl-3- } \\
\text { pentenyl)bicyclo[3.1.1]heptane }\end{array}$ & 26.70 & 0.033 & 0.04 \\
\hline 51 & Alpha-Calacorene & 27.15 & 0.015 & 0.02 \\
\hline 52 & Gamma-Curcumene & 27.44 & 0.026 & 0.03 \\
\hline 53 & Beta-Bisabolene & 27.57 & 0.080 & 0.10 \\
\hline 54 & 1,7-Octadiene, 2,7-dimethyl-3,6-bis(methylene)- & 28.00 & 0.015 & 0.02 \\
\hline 55 & Santolinatriene & 28.14 & 0.018 & 0.02 \\
\hline 56 & Gamma-Curcumene & 28.29 & 0.061 & 0.08 \\
\hline 57 & Alloaromadendrene & 28.68 & 0.021 & 0.03 \\
\hline 58 & Clovene & 29.32 & 0.018 & 0.02 \\
\hline 59 & Alpha-bergamotene & 30.12 & 0.064 & 0.08 \\
\hline \multirow[t]{2}{*}{60} & Tricosane & 42.37 & 0.028 & 0.04 \\
\hline & Total area & & 100.00 & \\
\hline
\end{tabular}

P. betle with a high concentration $(5 \%(\mathrm{v} / \mathrm{v}))$ seemed to affect the mite population at day 30 . Thus, we only observed this concentration at day 60 and it did not decrease the mite population. For $Z$. limonella treatment, the results indicated that this oil was insufficient to control T. mercedesae when concentrations of $1 \%$ and $10 \%(\mathrm{v} / \mathrm{v})$ were applied under field conditions. Environmental conditions can influence the differences observed between the acaricidal activity under laboratory and field conditions. We further tested different application methods to deliver the essential oil of A. krervanh. We selected methods that beekeepers can easily apply in the colony. Our results demonstrated that grease nor a sponge acted as good materials to distribute the oils to control mites in the colony under the field conditions in Thailand. This could be due to the surface property of the media or other as yet unknown properties. The viscosity of commercial grease may be a factor that reduce the release rate and distribution of essential oil in colony. On the contrary, the essential oil could be rapidly absorbed into the sponge and quickly evaporate when exposed to the air because the sponge had a large pore size. Therefore, these methods might not be suitable for essential oil delivery or may need more refinement as they have been used by Thai and other beekeepers to deliver some products within the hive. In this study, only liquid paraffin strips were assigned as negative control since liquid paraffin was used to dissolve the essential oil and the number of colonies available to test was limited. However, grease and sponge strips should be included as negative control in future experiments to fully test the effects of these carrier materials if they prove to be effective delivery media. Some essential oils that showed high activity to kill mites under laboratory did not exhibit control potential under whole colony conditions. Control 
Table IV. Chemical composition of essential oil used in this study

\begin{tabular}{|c|c|c|c|}
\hline \multirow[t]{2}{*}{ Essential oil } & \multicolumn{2}{|l|}{ Chemical composition } & \multirow[t]{2}{*}{ Reference } \\
\hline & Compound & $\%$ & \\
\hline \multirow[t]{3}{*}{ Amomum krervanh } & 1,8-Cineole & 77.17 & This study \\
\hline & $\beta$-Pinene & 8.43 & \\
\hline & $\alpha$-Terpineol & 4.58 & \\
\hline \multirow[t]{3}{*}{ Cinnamomum camphora } & D-Camphor & 40.5 & Guo et al. (2016) \\
\hline & Linalool & 22.9 & \\
\hline & 1,8-Cineole & 11.3 & \\
\hline \multirow[t]{2}{*}{ Cinnamomum sp. } & Cinnamaldehyde & $65.0-80.0$ & Rao and Gan (2014) \\
\hline & Eugenol & $5.0-10.0$ & \\
\hline \multirow[t]{5}{*}{ Citrus hystrix } & Terpinen-4-ol & 13.0 & Waikedre et al. (2010) \\
\hline & $\beta$-Pinene & 10.9 & \\
\hline & $\alpha$-Terpineol & 7.6 & \\
\hline & 1,8-Cineole & 6.4 & \\
\hline & Citronellal & 6.0 & \\
\hline \multirow[t]{2}{*}{ Cymbopogon citratus } & Geranial & $51.14-53.2$ & Pinto et al. (2015) \\
\hline & Citral & $35.21-36.37$ & \\
\hline \multirow[t]{4}{*}{ Eucalyptus globulus } & 1,8-Cineole & 55.29 & Harkat-Madouri et al. (2015) \\
\hline & Isovaleraldehyde & 10.04 & \\
\hline & $\alpha$-Terpineol & 5.46 & \\
\hline & $\alpha$-Pinene & 4.61 & \\
\hline \multirow[t]{2}{*}{ Ocimum basilicum } & Methyl eugenol & 39.3 & Joshi (2014) \\
\hline & Methyl chavicol & 38.3 & \\
\hline \multirow[t]{3}{*}{ Ocimum sanctum } & Eugenol & 46.2 & Awasthi and Dixit (2007) \\
\hline & (E)-caryophyllene & 27.6 & \\
\hline & $\beta$-elemene & 16.3 & \\
\hline \multirow[t]{2}{*}{ Piper betle } & Eugenol & Up to $40 \%$ & Salehi et al. (2019) \\
\hline & Carvacrol and Chavicol & Up to $40 \%$ & \\
\hline \multirow[t]{2}{*}{ Syzygium aromaticum } & Eugenol & 71.56 & Nassar et al. (2007) \\
\hline & Eugenol acetate & 8.99 & \\
\hline \multirow[t]{3}{*}{ Zanthoxylum limonella } & Limonene & 31.09 & Itthipanichpong et al. (2002) \\
\hline & Terpin-4-ol & 13.94 & \\
\hline & Sabinene & 9.13 & \\
\hline
\end{tabular}

failure at the colony level is not uncommon and Tropilaelaps control failures for essential oils could be due to numerous variables such as temperature and relative humidity. These variables likely affect evaporation rate and thus can affect the exposure of mites to essential oils. Considering the acaricidal activity under laboratory test and the reduced harm to bees demonstrated by several of these essential oils in the present study, differing application methods and concentrations should be further investigated at the colony level. Essential oils can offer alternative mite control options but are more sensitive to environmental and hive conditions than synthetic miticides in slow release strips. The limitations and challenges of applying essential oils to honeybee colonies should not deter us from trying to develop these promising mite control options. 
CODE AVAILABILITY

Not applicable

\section{AUTHOR CONTRIBUTION}

$\mathrm{VC}, \mathrm{NW}$, and JSP conceived this research and designed experiments; VC, TB, and JSP performed the experiments and data analysis; VC, NW, and JSP wrote the paper and participated in the revisions of it. All authors read and approved the final manuscript.

\section{FUNDING}

This research was financially supported by the Thailand Research Fund and Office of the Higher Education Commission (grant number MRG6280090) and USDA-APHIS under agreement number 588042-5-089F.

\section{DATA AVAILABILITY}

All data generated or analyzed during this study are included in this published article.

\section{DECLARATIONS}

Ethics approval Not applicable

\section{Consent to participate Not applicable}

Consent for publication Not applicable

Conflict of interest The authors declare no competing interests.

Activité acaricide des huiles essentielles pour la lutte contre les acariens de l'abeille (Apis mellifera) Tropilaelaps mercedesae en conditions de laboratoire et milieu naturel.

Tropilaelaps / activité acaricide / LC50 / Apis mellifera / Piper betle / Amomum krervanh.

Die akarizide Aktivität essentieller Öle für die Kontrolle der Milbe Tropilaelaps mercedesae der Honigbiene (Apis mellifera) unter Labor- und Feldbedingungen.
Tropilaelaps / akarizide AKtivität / LC50 / Apis mellifera / Piper betle / Amomum krervanh.

\section{REFERENCES}

Abd El-Wahab, T.E., Ebada, M.A. (2006). Evaluation of some volatile plant oils and Mavrik against Varroa destructor in honey bee colonies. J. Appl. Sci. Res. 2, 514-521.

Anderson, D.L., Morgan, M.J. (2007). Genetic and morphological variation of bee-parasitic Tropilaelaps mites (Acari: Laelapidae): new and re-defined species. Exp. Appl. Acarol. 43, 1-24.

Araújo, M.J.C., Câmara, C.A.G., Born, F.S., Moraes, M.M., Badji, C.A. (2012). Acaricidal activity and repellency of essential oil from Piper aduncum and its components against Tetranychus urticae. Exp. Appl. Acarol. 57, 139-155.

Atwal, A.A., Goyal, N.P. (1971). Infestation of honey bee colonies with Tropilaelaps, and its control. J. Apic. Res. 10, 137-142.

Awasthi, P.K., Dixit, S.C. (2007). Chemical compositions of Ocimum sanctum Shyama and Ocimum sanctum Rama oils from the plains of Northern India. J. Essent. Oil-Bear Plants 10, 292-296.

Bacandritsos, N., Papanastasiou, I., Saitanis, C., Nanetti, A., Roinioti, E. (2007). Efficacy of repeated trickle applications of oxalic acid in syrup for Varoosis control in Apis mellifera: influence of meteorological conditions and presence of brood. Vet. Parasitol. 148, 174-178.

Bendifallah, L., Belguendouz, R., Hamoudi, L., Arab, K. (2018). Biological activity of the Salvia officinalis L. (Lamiaceae) essential oil on Varroa destructor infested honeybees. Plants 7, 44.

Buawangpong, N., de Guzman, L.I., Khongphinitbunjong, K., Frake, A.M., Burgett, M., Chantawannakul, P. (2015). Prevalence and reproduction of Tropilaelaps mercedaesae and Varroa destructor in concurrently infested Apis mellifera colonies. Apidologie 46, 779786.

Burgett, D.M., Kitprasert, C. (1990). Evaluation of Apistan $^{\mathrm{TM}}$ as a control for Tropilaelaps clareae (Acari, Laelapidae), an Asian honey bee brood mite parasite. Am. Bee J. 130, 51-53.

Burgett, M., Akratanakul, P., Morse, R.A. (1983). Tropilaelaps clareae: a parasite of honeybees in south-east Asia. Bee World 64, 25-28.

Burley, L.M., Fell, R.D., Saacke, R.G. (2008). Survival of honey bee (Hymenoptera: Apidae) spermatozoa incubated at room temperature from drones exposed to miticides. J. Econ. Entomol. 101, 1081-1087.

Camphor, E.S.W., Hashmi, A.A., Ritter, W., Bowen, I.D. (2005). Seasonal changes in mite (Tropilaelaps 
clarae) and honeybee (Apis mellifera) populations in apistan treated and untreated colonies. Apiacta 40, 34 44.

Chaimanee, V., Thongtue, U., Sornmai, N., Songsri, S., Pettis, J.S. (2017). Antimicrobial activity of plant extracts against the honeybee pathogens, Paenibacillus larvae and Ascosphaera apis and their topical toxicity to Apis mellifera adults. J. Appl. Microbiol. 123, 1160-1167.

Chaimanee, V., Chantawannakul, P., Khongphinitbunjong, K., Kamyo, T., Pettis, J.S. (2019). Comparative pesticide exposure to Apis mellifera via honey beecollected pollen in agricultural and non-agricultural areas of Northern Thailand. J. Apic. Res. 58, 1-10.

Chen, Z., Guo, S., Cao, J., Pang, X., Geng, Z., Wang, Y., Zhang, Z., Du, S. (2018). Insecticidal and repellent activity of essential oil from Amomum villosum Lour. and its main compounds against two stored-product insects. Int. J. Food Prop. 21, 2265-2275.

Conti, B., Bocchino, R., Cosci, F., Ascrizzi, R., Flamini, G., Bedini, S. (2020). Essential oils against Varroa destructor: a soft way to fight the parasitic mite of Apis mellifera . J. Apic. Res. 59, 774-782.

da Silva Lima, A., do Nascimento Sousa Filho, J.G., Pereira, S.G., Skelding Pinheiro Guillon, G.M., da Silva Santos, L., Costa Júnior, L.M. (2014). Acaricide activity of different extracts from Piper tuberculatum fruits against Rhipicephalus microplus . Parasitol. Res. $113,107-112$.

Damiani, N., Gende, L.B., Bailac, P., Marcangeli, J.A., Eguaras, M.J. (2009). Acaricidal and insecticidal activity of essential oils on Varroa destructor (Acari: Varroidae) and Apis mellifera (Hymenoptera: Apidae). Parasitol. Res. 106, 145-152.

Diao, W.R., Zhang, L.L., Feng, S.S., Xu, J.G. (2014). Chemical composition, antibacterial activity and mechanism of action of the essential oil from Amomum kravanh. J. Food Prot. 77, 1740-1746.

Dwivedi, V., Tripathi, S. (2014). Review study on potential activity of Piper betle. J. Pharmacogn. Phytochem. 3, 93-98.

Evans, J.D., Chen, Y.P., di Prisco, G., Pettis, J., Williams, V. (2009). Bee cups: single-use cages for honey bee experiments. J. Apic. Res. 48, 300-302.

Ferraz, A.B.F., Balbino, J.M., Zini, C.A., Ribeiro, V.L.S., Bordignon, S.A.L., Von Poser, G. (2010). Acaricidal activity and chemical composition of essential oil from three Piper species. Parasitol. Res. 107, 243-248.

Gashout, H.A., Guzmán-Novoa, E. (2009). Acute toxicity of essential oils and other natural compounds to the parasitic mite, Varroa destructor, and to larval and adult worker honey vees (Apis mellifera L.). J. Apic. Res. 48, 263-269.

Guo, S., Geng, Z., Zhang, W., Liang, J., Wang, C., Deng, Z., Du, S. (2016). The chemical composition of essential oils from Cinnamomum camphora and their insecticidal activity against the stored product pests. Int. J. Mol. Sci. 17, 1836.
Haarmann, T., Spivak, M., Weaver, D., Weaver, B., Glenn, T. (2002). Effects of fluvalinate and coumaphos on queen honey bees (Hymenoptera: Apidae) in two commercial queen rearing operations. J. Econ. Entomol. 95, 28-35.

Harkat-Madouri, L., Asma, B., Madani, K., Said, Z.B-O.S., Rigou, P., Grenier, D., Allalou, H., Remini, H., Adjaoud, A., Boulekbache-Makhlouf, L. (2015). Chemical composition, antibacterial and antioxidant activities of essential oil of Eucalyptus globulus from Algeria. Ind. Crop. Prod. 78, 148-153.

Imdorf, A., Bogdanov, S., Ochoa, R.I., Calderone, N.W. (1999). Use of essential oils for the control of Varroa jacobsoni Oud. in honey bee colonies. Apidologie 30, 209-228.

Itthipanichpong, C., Ruangrungsi, N., Pattanaautsahakit, C. (2002). Chemical compositions and pharmacological effects of essential oil from the fruit of Zanthoxylum limonella. J. Med. Assoc. Thail. 85 (suppl. 1), 344354.

Joshi, R.K. (2014). Chemical composition and antimicrobial activity of the essential oil of Ocimum basilicum L. (sweet basil) from Western Ghats of North West Karnataka, India. Anc. Sci. Life 33, 151-156.

Kongpitak, P., Polgar, G., Heine, J. (2008). The efficacy of Bayvarol $\AA$ and Checkmite $+\circledR$ in the control of Tropilaelaps mercedesae in the European honey bee (Apis mellifera) in Thailand. Apiacta 43, 12-16.

Mathew, J., Shiburaj, S., George, V. (2003). Antimicrobial acitivity of Amomum cannicarpum. Fitoterapia 74, 476-478.

Mullin, C.A., Frazier, M., Frazier, J.L., Ashcraft, S., Simonds, R., vanEngelsdorp, D., Pettis, J.S. (2010). High levels of miticides and agrochemicals in North American apiaries: implications for honey bee health. PLoS ONE 5, e9754.

Nassar, M.I., Gaara, A.H., El-Ghorab, A.H., Farrag, AR.H., Shen, H., Huq, E., Mabry, T.J. (2007). Chemical constituents of clove (Syzygium aromaticum, Fam. Myrtaceae) and their antioxidant activity. Rev. Latinoamer. Quim. 35, 47-57.

Nuanjohn, T., Chaimanee, V. (2019). Effectiveness of some essential oils for control of Tropilaelaps mercedesae mites in honeybees (Apis mellifera L.). King Monkut's Agric. J. 37, 43-50.

Park, B-S., Lee, S-E., Choi, W-S., Jeong, C-Y., Song, C., Cho, K-Y. (2002). Insecticidal and acaricidal activity of pipernoline and piperoctadecalidine derived from dried fruits of Piper longum L. Crop Prot. 21, 249251 .

Pettis, J.S., Rose, R., Chaimanee, V. (2017). Chemical and cultural control of Tropilaelaps mercedesae mites in honeybee (Apis mellifera) colonies in Northern Thailand. PLoS ONE 12, e0188063.

Pinto, Z.T., Sanchez, F.F., dos Santos, A.R., Amaral, A.C.F., Ferreira, J.L.P., Escalona-Arranz, J.C., Queiroz, M.M.de C. (2015). Chemical composition and insecticidal activity of Cymbopogon citratus essential oil from Cuba and Brazil against housefly. Braz. J. Vet. Parasitol. 24, 36-44. 
Pradhan, D., Suri, K.A., Pradhan, D.K., Biswasroy, P. (2013). Golden heart of the nature: Piper betle L. J. Pharmacogn. Phytochem. 1, 147-167.

Pulbutr, P., Caichompoo, W., Lertsatithanakorn, P., Phadungkit, M., Rattanakiat, S. (2012). Antibacterial activity, antimutagenic activity and cytotoxic effect of an essential oil obtained from Amomum uliginosum K.D. Koenig. J. Biol. Sci. 12, 355-360.

Raffique, M.K., Mahmood, R., Aslam, M., Sarwar, G. (2012). Control of Tropilaelaps clareae mite by using formic acid and thymol in honey bee Apis mellifera colonies. Pak. J. Zool. 44, 1129-1135.

Rao, P.V., Gan, S.H. (2014). Cinnamon: A multifaceted medicinal plant. Evid. Based Complement. Alternat. Med. https://doi.org/10.1155/2014/642942.

Ritter, W. (2008). Tropilaelaps infestation of honey bees (Tropilaelaps spp.). pp. 419-423. In: OIE Biological Standard Commission (ed.), Manual of Diagnostic Tests and Vaccines for Terrestrial Animals. World Organisation for Animal Health, Paris, France.

Ritter, W., Schnieder-Ritter, U. (1988). Differences in biology and means of controlling Varroa jacobsoni and Tropilaelaps clareae, two novel parasitic mites of Apis mellifera. In: Africanized honeybees and bee mites, proceedings. WicWas Press.

Rosenkranz, P., Aumeier, P., Ziegelmann, B. (2010). Biology and control of Varroa destructor. J. Invertebr. Pathol. 103, S96-S119.

Ruffinengo, S., Eguaras, M., Floris, I., Faverin, C., Bailac, P., Ponzi, M. (2005). $\mathrm{LD}_{50}$ and repellent effects of essential oils from Argentinian wild plant species on Varroa destructor. J. Econ. Entomol. 98, 651-655.

Salehi, B., Zakaria, Z.A., Gyawali, R., Ibrahim, S.A., Rajkovic, J., Shinwari, Z.K. Khan, T., Sharifi-Rad, J., Ozleyen, A., Turkdonmez, E., Valussi, M., Tumer, T.B., Fidalgo, L.M., Martorell, M., Setzer, W.N. (2019). Piper species: A comprehensive review on their phytochemistry, biological activities and applications. Molecules 24, 1364.

Sammataro, D., Gerson, U., Needham, G. (2000). Parasitic mites of honey bees: life history, implications and impact. Annu. Rev. Entimol 45, 519-548.

Satyal, P., Dosoky, N.S., Kincer, B.L., Setzer, W.N. (2012). Chemical compositions and biological activities of Amomum subulatum essential oils from Nepal. Nat. Prod. Commun. 7, 1233-1236.

Silva, W.C., Martins, J.R., de Souza, H.E., Heinzen, H., Cesio, M.V., Mato, M., Albrecht, F., de Azevedo, J.L., de Barros, N.M. (2009). Toxicity of Piper aduncum L. (Piperales: Piperaceae) from the Amazon forest for the cattle tick Rhipicephalus (Boophilus) microplus (Acari: Ixodidae). Vet. Parasitol. 164, 267-274.

Singtothong, C., Gagnon, M.J., Legault, J. (2013). Chemical composition and biological activity of essential oil of Amomum biflorum. Nat. Prod. Commun. 8, 265267.

Vinturelle, R., Mattos, C., Meloni, J., Nogueira, J., Nunes, M.J., Vaz Jr, I.S., Rocha, L., Lione, V., Castro, H.C., Folly das Chagas, E. (2017). In vitro Evaluation of essential oils derived from Piper nigrum (Piperaceae) and Citrus limonum (Rutaceae) against the tick Rhipicephalus (Boophilus) microplus (Acari: Ixodidae). Biochem. Res. Int. 1-9.

Waikedre, J., Dugay, A., Barrachina, I., Herrenknecht, C., Cabalion, P., Fournet, A. (2010). Chemical composition and antimicrobial activity of the essential oils from New Caledonian Citrus macroptera and Citrus hystrix. Chem. Biodivers. 7, 871-877.

Publisher's note Springer Nature remains neutral with regard to jurisdictional claims in published maps and institutional affiliations. 